Tanja Čelebič,

Msc.

Ulrad RS za

makroekonomske

analize in razvoj

\section{NEFORMALNO IZOBRAŽEVANJE V SLOVENIJI Z MEDNARODNO PRIMERJAVO PO ANKETI O IZOBRAŽEVANJU ODRASLIH}

\section{POVZETEK}

Avtorica v prispevku prikazuje stanje in značilnosti neformalnega izobraževanja odraslih v Sloveniji v mednarodni primerjavi z EU-27. Analiza je narejena za leto 2007 na podlagi podatkov Ankete o izobraževanju odraslih, ki je prva taka anketa na

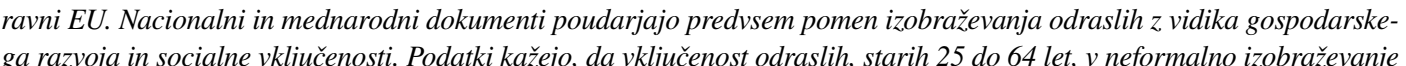
presega povprečje EU-27, vendar pa se v vključenosti kažejo velike razlike glede na starost, doseženo izobrazbo, status aktivnosti in poklic. Podobno se kažejo tudi razlike v povprečnem trajanju izobraževanja na udeleženca. Večina izobraževanja je povezana s potrebami dela, a je delež manjši od povpreč̆ja EU-27. Najpogostejš̌ r razlog za izobraževanje je razvoj kariere ali izbolisanje kariernih možnosti, drugi razlogi so veliko manj pomembni. V strukturi udeležencev neformalnega izobraževanja po podroçith izobrażevanja najveçi deleż odpade na druzbene vede, poslovne vede in pravo, Slovenja od povprečja odraslih v izobraževanje, predvsem tistih skupin, ki se redkeje vkliučujejo v izobraževanje. Ker je pogosta ovira v izobraže vanju odraslih krajevna nedostopnost izobră̌evanja, bi bilo treba spodbujati enakomernejšo razporeditev organizacij, $k i$ izvajajo neformalno izobră̌vanje. Spodbujati bi bilo treba tudi pogosteǰš rabo interneta, ki je pomemben vir informacijo izobraževalnih možnostih, predvsem pri nizko izobraženih in starejšsh

Ključne besede: neformalno izobraževanje, izobraževanje odraslih, vključenost odraslih v izobraževanje, spodbude za izobraževanje, socio-ekonomski vidiki izobraževanja odraslih

NON-FORMAL EDUCATION IN SLOVENIA, COMPARED TO EU 27 - ABSTRACT The author represents in the article the situation and caracteristics of non-formal education in Slovenia compared to $E U$ 27. The analysis is based upon the Adult education data for year 2007 , which is the first such survey on EU level. The data show, that the participation of persons, aged 25-64, in non-formal education exceeds the EU-27 average, but there are hugh differences in participation with regard to age, formal education, activity status and occupation. Smilary, the differences in mean instruction hours spent by participant on non-formal education can be seen. The majority of education is linked to job-related non-formal education, but the share is lower compared to EU-27 average. The most important reason of participation in non-formal education is to do job better and/for improve carrier prospects, while the orther reasons are less important. In the structure of non-formal education by the fields of education the highest share represents the field social sciences, business and law. The biggest difference to EU-27 average is in the field of foreign languages. Participation of reachable distance is frequent obstacle in education, that's why more equal teritorial allocation of provider of non-formal education should be encouraged. Also more frequent internet use, which is the important source of education opportunities, specially among low qualified and older persons should be encouraged.

Keywords: non-formal education, adult education, the participation of adults in education, support for education, socio-economic aspects of adult education.

Vseživljenjsko učenje nastopa v domačih straeških in drugih dokumentih (Strategija vsežvljenjskosti učenja v Sloveniji, 2007; Strategija razvoja Slovenije, 2005; Okvir gospodarskih in socialnih reform za povečanje blaginje $\mathrm{v}$ Sloveniji, 2005; Operativni program razvoja človeških virov za obdobje 2007-2013, 2007) kot pomemben dejavnik socialne vključenosti in gospodarskega razvoja. Strategija vseživljenjskosti učenja v Sloveniji (2007) omenja pomen izobraževanja za uspešno in kakovostno delo in poklicno kariero, pomen splošnega izobraževanja ter izobraževanja za aktivno državljanstvo. Strategija razvoja Slovenije (2005: 30,38) postavlja v ospredje pomen izobražej z vidka gospodaje pomen izin ned drugin predviceva na podrocju vljenjskega učenja spodbujanje povpraševanja posameznikov po izobraževanju in usposabljanju, spodbujanje večjega vlaganja delodajalcev ter povečanje privlačnosti in dostopnosti izobraževanja in usposabljanja. Podobno Operativni program razvoja človeških virov za obdobje 2007-2013 (2007) omenja bujanje izobra slih zapostenth, izobrayevanje in usposaljanje brezposelnih ter izboljšanje dostopnosti različnih programov in oblik vseživljenjskega učenja. Okvir gospodarskih in socialnih reform za povečanje blaginje v Sloveniji (2005: 114) predvideva spodbujanje in omogočanje vseživljenjskega učenja V evropskih dokumentih vseživljenjsko učenje pomeni način za zmanjšanje socialne izključenosti in revščine ter razvijanje aktivnega državljanstva, dokumenti poudarjajo tudi potrebo po povečanju vključenosti odraslih v izobraževanje, predvsem iz prikrajšanih skupin. Memorandum o vseživljenjskem učenju (2000) poudarja, da mora postati vseživljenjsko učenje vodi čelo za ponudbo in udeležbo v celotnem kontinuumu učnih vsebin. Evropski dokumenti omenjajo enakost in dostopnost za tiste skupine prebivalstva, ki zaradi izobraževalne prikrajšanosti potrebujejo posebno podporo za izpolnitev svojega izobrazbenega potenciala: osebe s šibkimi osnovnimi znanji, predvsem s pomanjkljivo pismenostjo, zgodnji osipni-

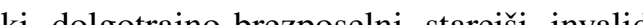
migranti in osebe, ki se po delgi odsonosi vračajo na delono mesto (Spočilo Komisije Svetu in Evropskemu parlamentu Učinkovitost in pravičnost $\mathrm{v}$ evropskih sistemih izo-

braževanja in usposabljanja, 2006; Sporočilo Komisije Izobraževanje odraslih: za učenje nikoli prepozno, 2006; Akcijski načrt za izobraževanje odraslih: za učenje je vedno pravi čas, 2007, ipd.).

Nekateri družbeni procesi (tehnološki napredek in globalizacija, staranje prebivalstva) pomembno vplivajo na vlogo izobraževanja odraslih. Projekcije veščin kažejo na povečanje zahtevnosti dela in povečevanje kvalifikacijskih zahtev v vseh poklicnih skupinah, kar ima posledice tudi za izobraževanje odraslih, ki omogoča prilagajanje znanja in veščin spreminjajočim se potrebam trga dela (Skill . Na pomen izobraževanja odraslih pomembno vplivajo tudi demografske spremembe. Prebivalstvo se stara, po Eurostatovih projekcijah gibanja prebivalstva (konvergenčni scenarij do leta 2060) naj bi se $\mathrm{v}$ prihodnjih desetletjih močno spremenila starostna struktura prebivalstva. Zmanjšala se bosta deleža mladega (0-14 let) in delovno sposobnega prebivalstva (15-64 let), močno pa se bo povečal delež starega prebivalstva (65 let in vec). To bo inelo tudi posledice za trg dela in podaljševanje delovne aktivnosti. Pomembno vlogo pri tem ima lahko izobraževanje odraslih, ki pripomore k ohranjanju zaposljivosti in prilagodljivosti starejših zaposlenih na trgu dela.

$\mathrm{V}$ prispevku na podlagi podatkov Ankete o izobraževanju odraslih (Adult Education Survey) za leto 2007 prikazujemo glavne izsledke o izbranih vidiki neformalnega izobraževanja od-

Družbeni procesi, kot sta tehnološki napredek in globalizacija, pomembno vplivajo na izobrazevanje odraslih. trajanje izobrž vanj na udeleženca, nocho izobraževanja, razlogi za izobražce, ne, poprimerjavo z EU-27. 
METODOLOŠKE ZNAČILNOSTI ANETE O IZOBRAŽEVANIU ODRASLIH

Za potrebe analitičnega spremljanja izobraževanja odraslih obstajajo na ravni EU različn statistični viri oziroma statistična raziskovanja: vprašalnik UOE, ${ }^{1}$ Anketa o delovni sili (ADS), Priložnostni modul o vseživljenjskem učenju (2003), Statistično raziskovanje (vprašalnik) o nadaljnjem poklicnem izobraževanju in usposabljanju zaposlenih v podjetjih in organizacijah (CVTS), Anketa o porabi časa, Anketa o življenjskih pogojih (EU - SILC). Ob tem na ravni EU potekata spremljanje in razvoj novih, mednarodno primerljivih statističnih podatkov in kazalnikov s področja vseživljenjskega učenja z namenom informiranja politike izobraževanja in zaposlovanja, spremljanja uresničevanja ukrepov politike in mednarodnih primerjav držav. S tem namenom je bila razvita tudi mednarodna raziskava Anketa o izobraževanju odraslih (2007), k sodi na ravni EU v okvir statistike o vseživljenjskem učenju.

Anketa o izobraževanju odraslih se je izvajala $v$ obdobju 2005-2008 v državah EU, EFTA in državah kandidatkah za vstop v EU. Namen je, da bi se izvajala na vsakih pet let. Referenčno leto ankete je 2007. V Anketo o izobraževanju odraslih je bila zajeta populacija v starosti 2564 let. Vir podatkov je posameznik, podatki so bili pridoblieni s telefonskim in terenskim anketiranjem. V anketo niso zajeti posameznili, ki prebivajo $v$ ustanove (zapoih, donovih starejše ipd). Anketiranci so poročali o izobraževalnih dejavnostih v obdobju zadnjih $12 \mathrm{me}-$ secev ali v zadnjem koledarskem letu. V Sloveniji so anketiranci poročali o izobraževalnih dejavnostih v obdobju zadnjih 12 mesecev pred anketiranjem. V anketo so bile v Sloveniji zajete posamezne osebe, ki živijo $\mathrm{v}$ individualnih gospodinjstvih in so stare 25-64 let, v vzorec je bilo izbranih 7.200 oseb (Izobraževanje odraslih po Anketi o izobraževanju odraslih 2007, 2010). Glavni namen Ankete o izobraževanju odrasli je pridobiti podatke o udeležbi in neudeležbi odraslih v izobraževanju. Anketa omogoča analizo podatkov o udeležbi in neudeležbi odraslih $v$ formalnem in neformalnem izobraževanje ter informalnem učenju, značilnostih učnih aktivnosti, v katere se vključujejo odrasli, obsegu ur, namenjenih za izobraževanje, izdatkih in financiranju izobržconja pripravlenosti za izobracravo izobž izobraZevanje, razlogih za vkljuçitev v izobraževanje, ovirah pri vključevanju v izobraževanje ter dostopnosti informacij o izobraževanju. Anketa tako omogoča analizo različnih statističnih podatkov, ki jih druge ankete ne ponujajo. Možno je analizirati različne vrste podatkov glede na izbrane socio-ekonomske značilnosti udeležencev izobraževanj, na podlagi drugih st tističnih raziskovanj so večinoma dosegljivi podatki o vključenosti odraslih v izobraževanje po spolu in starosti, redkeje po izobrazbi.

V Anketi o izobraževanju odraslih so dosegljivi podatki o vključenosti v izobraževanje in nekaterih drugih spremenljivkah po spolu, starosti, formalni izobrazbi, statusu aktivnosti, poklicu in gostoti poseljenosti (Adult education survey - AES, 2009). Zar 2009). Zaradi metodoloskih razllk podatki iz Ankete o izobraževanju odrasilh $Z$ drugimi statističnimi raziskovanji med seboj niso neposredno primerljivi. Med statističnimi raziskovanji obstajajo razlike glede namena, enote opazovanja, obdobja opazovanja in pogostosti izvajanja statističnega raziskovanja. V nadaljevanju prikazujemo izbrane kazalnike neformalnega izobraževanja odraslin po Anketi o izobraževanju odraslih. ${ }^{2}$

\section{VKLJUČENOST ODRASLIH V}

\section{NEFORMALNO IZOBRAŽEVANJE}

Vključenost odraslih, starih 25-64 let, v Sloveniji $\mathrm{v}$ neformalno izobraževanje je razmeroma velika. V letu 2007 je znašala 36,2 odstotka in je presegala povprečje EU-27 za 3,5 odstotne

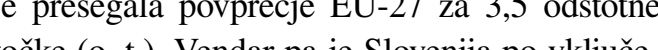
tocke (o. t.). Vendar pa je Slovenija po vključenosti močno zaostajala za gospodarsko razvitejsima severnoevropskima državama (Švedska, Finska), ki imata najvišji stopnji vključenosti v neformalno izobraževanje.
Slika 1: Vkliučenost odraslih, starih 25-64 let,
neformalno izobraževanie, 2007, EU-27, v \%

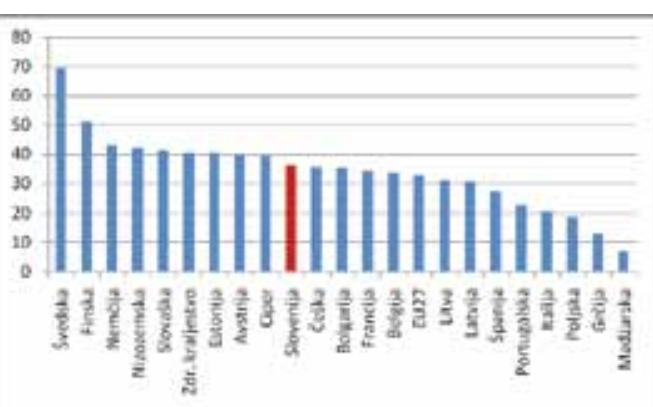

Vir: Eurostat, Anketa o izobraževaniu odraslih.

$\mathrm{Na}$ vključenost odraslih $\mathrm{v}$ izobraževanje vplivajo razni dejavniki: psihološki, sociološki, interakcija med posameznikom in okoljem. Psihološki dejavniki so posameznikovi motivi, osebnostne značilnosti, izkušnje v zgodnjem otroštvu. Po psiholoških teorijah na vključenost posameznika $\mathrm{v}$ izobraževanje vplivajo notranji dejavniki (dejavniki, ki izvirajo iz posameznika). Sociološke razlage poskuš ciološke razlage poskusajo vkjučenost izobraževanje razložiti z zunanji dejavnik (značilnosti družbe, izobraževalne politike, podjetja oziroma organizacije ipd.). Po interaktivnem pristopu na vključenost $v$ izobraževanje vpliva interakcija med posameznikom in okoljem. Na vključenost izobraževanje tako vplivajo pričakovanja ževanju, socializacija v družini, šoli in pr delu, možnosti za izobraževanje ipd. (Manninen, 2005: 13-18) posameznika, njegove potrebe po izobra-
Podatki Ankete o izobraževanju odraslih kažejo, da kljub mednarodno primerjalno raz meroma ugodnemu položaju pri vkljucenosti $\vee$ neformalno izobraževanje obstajajo velike razlike glede na socio-ekonomske značilnosti. To se ujema ugotitumi raznih šudij, navajajo, da se $v$ vključenosti navajajo, da se v vkljucenost odraslih v izobraževanje kažejo razlike glede na socio-ekonomske značilnosti (Pfeiffer, 2000: 18; Manninen, 2006: 11; Skaalvik, Levin, 2003: 35; Hollenbeck, 2008: 2-3).

S starostjo se praviloma vključenost odraslih v neformalno izobraževanje zmanjšuje, saj se zmanjšujejo pričakovane koristi od izobraževanja. Zato so starejši redkeje ko mlajši pripravljeni vključiti se v izobraževanje. Podatki Ankete o izobraževanju kažejo, da je vključenost odraslih $v$ neformalno izobraževanje največja v srednji starostni skupini (35-54 let), skoraj enaka je v najinlaji ptarostni skupini (25-34 let), medtem ko je

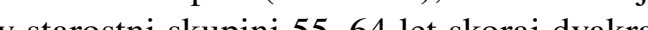
manjǔ. Majhna vključenost stajejh v for formalno izobraževanje je povezana tudi tem, da velik del vključenosti odpade na izobraževanje, povezano z delom, stopnja delovne aktivnosti pa je pri starejših nizka. Pri starejših lahko pomembno oviro pri vkljuceva ju vizobraževanju ustvari tudi predsodek, da so za izobraževanje že prestari. To potrjujejo podatki, saj je 20,6 odstotka starejših, ki se niso izobraževali, pa so si želeli,
Vključenost žensk v neformalno izobraževanje v Sloveniji je večja od vključenosti moških. V letu 2007 je znašala 37,9 odstotka in je za 3,4 o. t. presegala vključenost moških v izobraževanje. To je ravno nasprotno od povprečja EU-27, kjer je vključenost žensk v neformalno izobraževanje manjša od vključenosti moških. Večja vključenost žensk $v$ izobraževanje $v$ primerjavi z moškimi je verjetno tudi posledica višje stopnje delovne aktivnosti žensk v primerjavi z moškimi. 
kot razlog navedlo starost ali zdravje. Razlike v vključenosti v neformalno izobraževanje med najmlajšo in najstarejšo obravnavano starostno skupino so v Sloveniji večje kot na ravni EU-27.

Na vključenost odraslih v izobraževanje pomembno vpliva tudi dosežena izobrazba. Vključenost $\mathrm{v}$ izobraževanje praviloma narašča $\mathrm{z}$ višanjem dosežene izobrazbe. Tuje izkušnje kažejo, da se nizko izobraženi v povprečju redkeje vključujejo v izobraževanje kot srednješolsko in terciarno ${ }^{3}$ izobraženi. Bolje izobraženi zaposleni imajo boljši dostop do neformalnega izobraževanja (Fasih, 2008: 14) in so praviloma pogosteje vključeni v izobraževanje na pobudo delodajalca kot niže izobraženi (Levin, 2003: 34; Hollenbeck, 2008: 2-3). Tudi podatk Ankete o izobraževanju odraslih za Slovenijo potrjujejo navedbe tujih študij. Vključenost nizko izobraženih (največ s končano osnovno šolo) v neformalno izobraževanje je v Sloveniji majhna in močno zaostaja za vključenostjo srednješolsko in terciarno izobraženih. V letu 2007 je znašala 10,9 odstotka in je bila 5,8-krat manjša od vklju-
čenosti terciarno izobraženih

Vključenost $v$ izobraževanje pra-

viloma narašca z višanjem dosežene izobrazbe, položajem zaposlenega, krajem bivanja... $\mathrm{v}$ neformalno izobraževanje. Velika ovira vključenosti nizko izobraženih $\mathrm{v}$ neformalno izobraževanje je predrago izobraževanje oziroma da si posameznik izobraževanja ni mogel privoščiti. To oviro je navedlo 68,1 odstotka nizko izobraženih, ki se v izobraževanje niso vključili, pa so si to želeli. Razlike v vključenosti $v$ neformalno izobraževanje med različnimi Gebra zobrazbenimi skuphevami prebivalstva so v Sloveniji veliko večje kot na ravni povprečja EU-27. Vključenost nizko izobraženih v izobraževanje je tudi manjša od povprečja EU27 , medtem ko pri vključenosti srednješol- sko in terciarno izobraženih $\mathrm{v}$ neformalno zobraževanje Slovenija presega povprečje EU-27.

Brezposelni se praviloma redkeje vključujejo $\mathrm{v}$ izobraževanje kot zaposleni, delno zaposleni redkeje kot zaposleni za polni delovni čas, samozaposleni redkeje kot zaposleni. V Sloveje vključenost v neformalno izobraževanje po statusu aktivnosti največja pri zaposlenih (43,6 odstotka v letu 2007), kjer je približno dvakrat večja od vključenosti brezposelnih $\mathrm{v}$ izobraževanje in 2,6-krat večja od vključenosti neaktivnih.

$\mathrm{Na}$ vključenost zaposlenih $\mathrm{v}$ izobraževanje pomembno vpliva tudi položaj zaposlenega $\mathrm{v}$ podjetju oziroma organizaciji. Posamezniki, ki opravljajo manj zahtevna dela, se v povprečju redkeje vključujejo $\mathrm{v}$ izobraževanje kot posamezniki, ki opravljajo zahtevnejša dela. V Sloveniji je vključenost zaposlenih $\mathrm{v}$ neformalno izobraževanje največja v poklicni skupini SKP $1-3{ }^{4}$ ki opravlja intelektulno bolj zahtevna dela in dela, in najmanjsa v poklicni skupini SKP 8-9.5 Vključenost $\mathrm{v}$ neformalno izobraževanje se $\mathrm{z}$ nižanjem ravni zahtevnosti poklicev zmanjšuje. Razlike v vključenosti v neformalno izobraževanje med poklicno skupino SKP 1-3 in SKP 8-9 so v Sloveniji večje od povprečja EU-27.

V vključenosti v neformalno izobraževanje se kažejo tudi razlike glede na območje bivanja. Vključenost $\mathrm{v}$ izobraževanje je navadno večja pri osebah, ki bivajo na urbanih območjih, in manjša pri osebah, ki bivajo na podeželju. Vključenost $\mathrm{v}$ izobraževanje je praviloma večja pri osebah, ki bivajo na gosto poseljenih območjih. Tudi v Sloveniji se kažejo razlike v ključenosti v izobrǎ̌evanje glede na gostovostoposelitue, vendar pa so te razlike razmeroin migracijami prebivalstva zaradi dela $\mathrm{v}$ mesta, kjer je obenem zgoščena ponudba izobraževanja.
Slika 2: Vkliučenost odraslih, starih
25-64 let, v neformalno izobraževanie, glede na socio-ekonomske značilnosti,
2007 , Slovenija in povprečie EU-27, $\%$ \%

Vir: Eurostat, Anketa o izobraževaniu odraslih. Opomba: Po SKP so: zakonodajalci, visoki uradniki in menedžerii ( SKP 1), strokovnniaki (SKP 21, tehniki in drugi strokovni sodelavci (SKP 3),
uradniki (SKP 4), poklici za storitve, proddialci (SKP 5), kmetovalci, gozdarii, ribici, lovci (SKP 6), poklici za neindustrijski način dela (SKP 7), upravliavci strojer in naprav, industrijiski izdelovalci in sestavljavci (SKP 8) in poklici za preprosta dela (SKP 9).

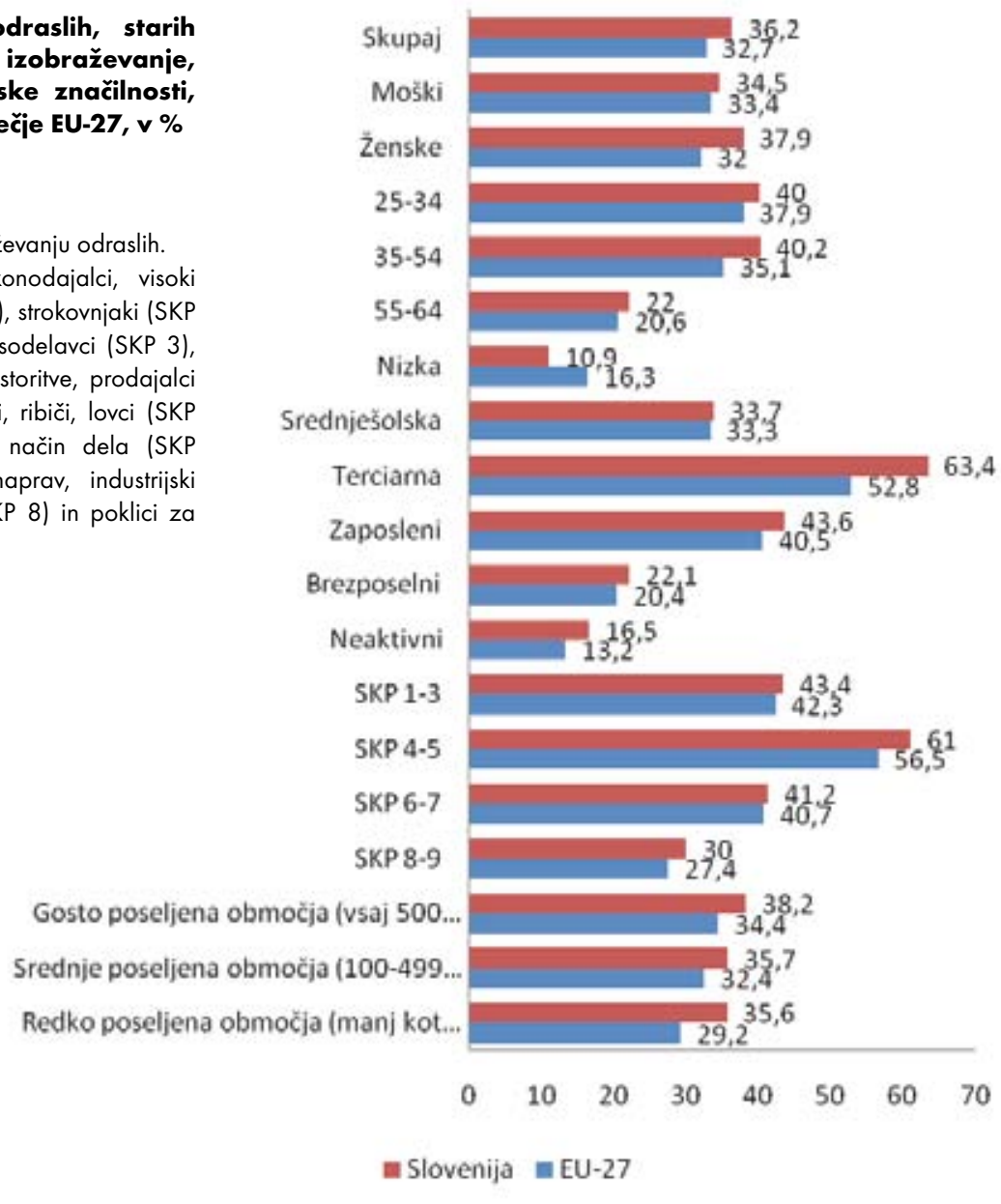

TRAJANJE UDELEŽBE V NEFORMALNEM IZOBRAŽEVANIU

Poleg vključenosti v izobraževanje dodatno informacijo o izobrě̌evanju odralih daje podatki o trajanju udeležbe $\mathrm{v}$ izobraževanju (povprečno število ur izobraževanja na posameznika $^{6}$ ali udeleženca izobraževanja). Anketa o izobraževanju odraslih prikazuje povprečno število ur izobraževanja na udeleženca, kar predstavljamo v tem poglavju. Kazalnik povprečno število ur izobroževanja na udeleženca izobrževa ju je pi medna primerjavah siscluno opazovali skupaj skazalnikom vključenost $v$ izobraževanje, in sice z namenom, da se vidi, ali obstaja med njim povezava. Večje število ur trajanja izobraže- vanja na udeleženca izobraževanja ne pomen nujno tudi večje vključenosti $v$ izobraževanje in obratno.

Slovenija, kot smo že omenili, po vključenosti odraslih v neformalno izobraževanje presega povprečje EU-27, vendar po povprečnem številu ur izobraževanja na udeleženca z 49 urami močno zaostaja za povprečjem EU-27. Primerjava med podatki o vključenosti odraslih $v$ neformalno izobraževanje in povprečnim tajanjem izobraževaja na udeleženca pokaže, da je pri nas vključ v izobraževanja večja od povprečj vendar paja večja od povprečja EU-27, ženca ženca krajše. 


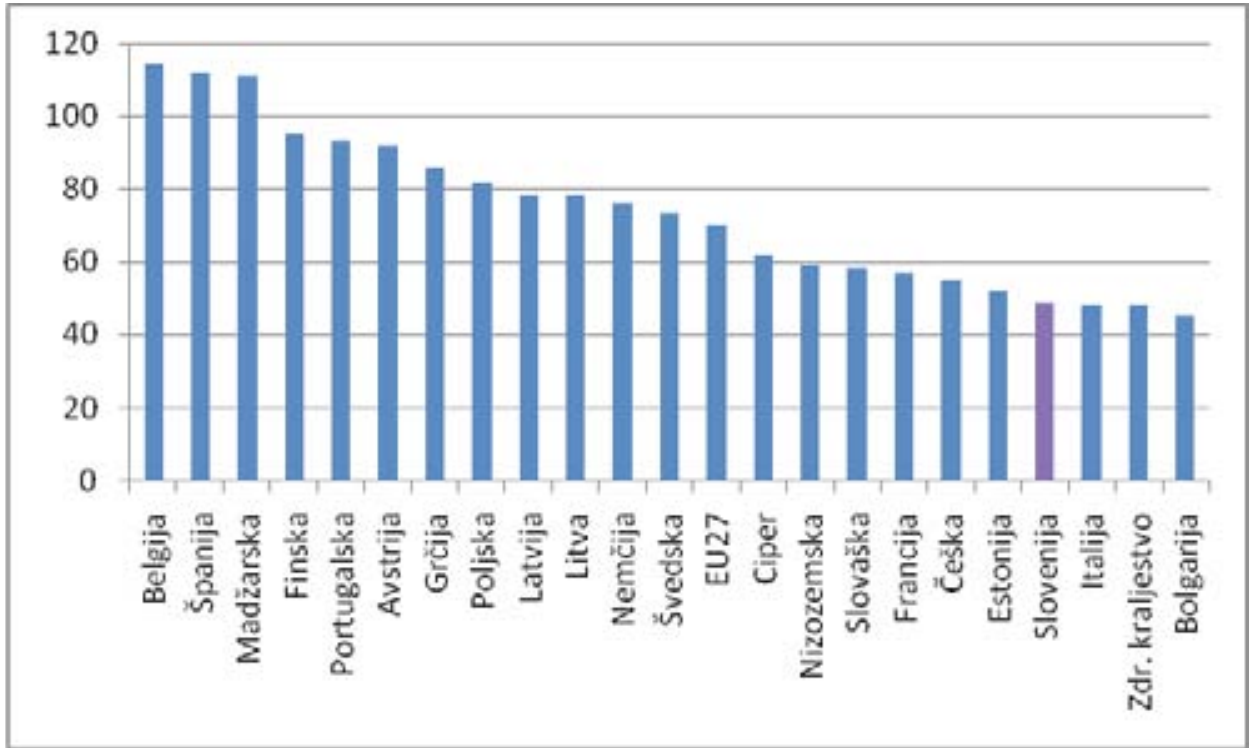

Vir: Eurostat, Anketa o izobraževanju odraslih.

$\checkmark$ povprečnem številu ur neformalnega izobraževanja na udeleženca se kažejo tudi razlike glede na socio-ekonomske značilnosti. Povprečno število ur neformalnega izobraževanja je glede na starost največje $\mathrm{v}$ najstarejši starostni skupini (55-64 let), kjer je za eno uro daljše kot pri najmlajši starostni skupini (25-34 let). Najkrajše trajanje izobraževanja na udeleženca je $\mathrm{v}$ srednji starostni skupini. S tem Slovenija odstopa od povprečja EU-27, kjer se povprečno trajanje zobraževania na udeleženca s staç . Dolo pouprečno tajaje izobraževjsuje. Dolgo povpečzo trajaje izobrzevanja na udeleženca $v$ starostni skupini 55-64 let je verjetno povezano tudi z nižjo stopnjo delovne aktivnosti v tej skupini, saj so pri tej populaciji manj izražene ovire $\mathrm{v}$ izobraževanju, povezane $\mathrm{z}$ delom (izobraževanje se ni ujemalo z urnikom dela). Poleg tega se ta populacija praktično ne vključuje v formalno izobraževanje in lahko več časa nameni neformalnemu izobraževanju. Vključenost starejših v neformalno izobraževanje je manjša kot pri mlajših, tisti starejši, ki se vključujejo v izobraževanje, pa ostanejo vkljuceni dlje časa. V srednji starostni skupini je vključenost $v$ izobraževanje večja, a je trajanje izobraževanja krajše. Pri tej starostni skupini so poleg ovir v izobreževanu, povezanih $z$ delom, pogosteǰ v izir se dhy̆inke obeznosi. Zaostanek Slovenije v povprečnem traja ju Zaoževanja na udeleženca za povprečjem EU-27 je največji pri najmlajši starostni skupini (25-34 let) in najmanjši pri najstarejši starostni skupini (55-64 let).

Povprečno trajanje izobraževanja na udeleženca glede na izobrazbo se podobno kot vključenost $\mathrm{v}$ izobraževanje podaljšuje $\mathrm{z}$ višanjem stopnje dosežene izobrazbe. Kaže se precejšen zaostanek povprečnega trajanja izobraževanja pri nizko izobraženih za srednješolsko in terciarno izobraženimi. Ne le, da je vključenost nizko izobraženih $\mathrm{v}$ neformalno izobraževanje zelo majhna, ampak je tudi povprečno trajanje (je zzobraže prì srednješolsko in terciarno izobraženih. Po tem se Slovenija razlikuje od povprečja EU-27, kjer je ravno pri nizko izobraženih trajanje udeležbe v neformalnem izobraževanju najdaljše

Glede na status aktivnosti je povprečno trajanje neformalnega izobraževanja najdalǰ̌e pri brezposelnih, kjer je približno dvakrat daljše kot pri zaposlenih, a je vključenost v izobraževanje približno dvakrat manjša kot pri zaposlenih. Podobno je tudi na ravni EU-27 povprečno trajanje neformalnega izobraževanja najdalǰse pri brezposelnih, kjer močno presega povprečno trajanje pri zaposlenih. Vendar pa Slovenija po povprečnem številu ur izobraževanja na udeleženca ravno pri brezposelnih močno zaostaja za evropskim povprečjem. Glede na poklic je najdalǰše trajanje neformalnega izobraže作 povprečno trajanje neformalnega izobraževanja pri poklicni skupini ISCO 8-9.

Slika 4: Povprečno število ur izobraževanja na udeleženca neformalnega izobraževanja po socio-

(t)

=EU-27 = Slovenija

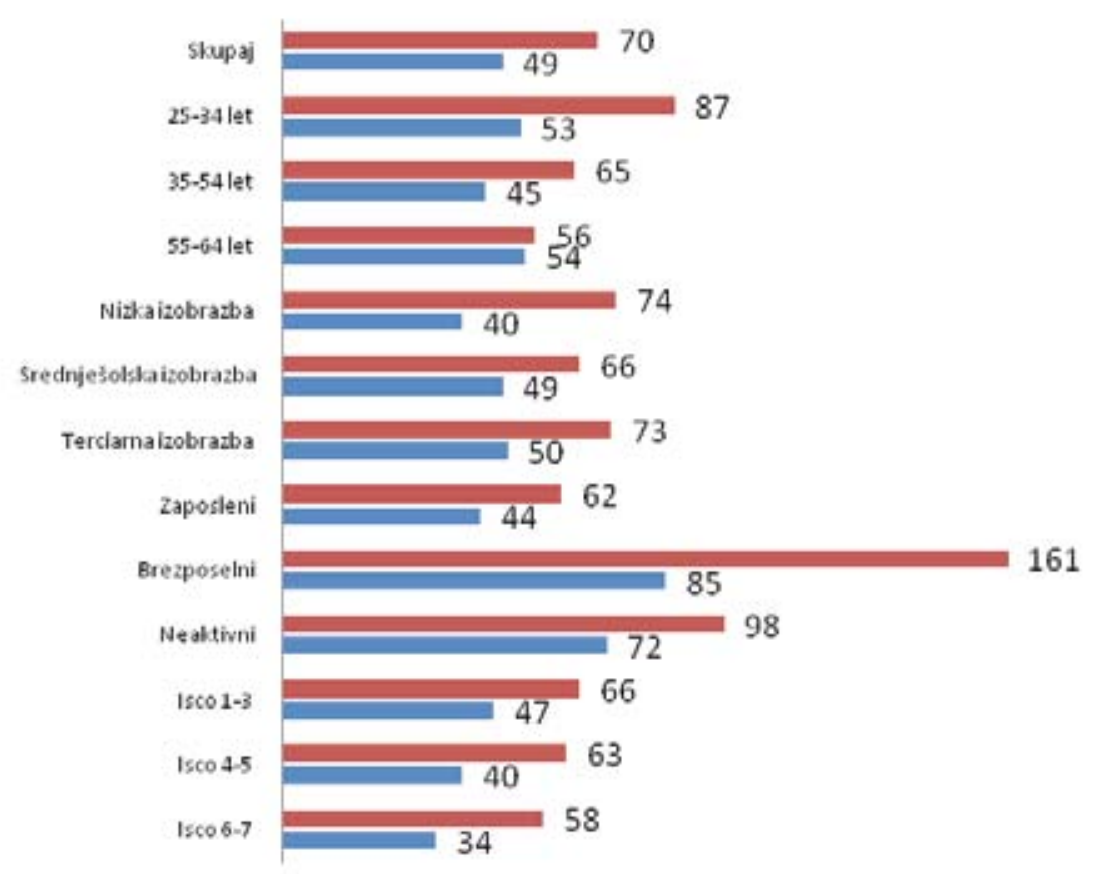

Vir: Eurostat, Anketa o izobraževanju odraslih.

Opomba: Podatka o traianiu izobraževania na udeleženca po spolu in glede na gostoto poselitive nista na volio.

\section{NAMEN IZOBRAŽEVANIA}

Posameznik se lahko v izobraževanje vključi zaradi potreb, povezanih $\mathrm{z}$ delom, ali zaradi potreb, povezanih z osebnostnim razvojem, aktivnim državljanstvom ipd. V Sloveniji se večina oseb vključuje $\mathrm{v} z$ delom povezano ne- formalno izobraževanje (70,8 odstotka v letu 2007). Preostali so bili vključeni le v izobraževanje, ki ni povezano z delom. Slovenija odstopa od povprečja EU-27, kjer je delež oseb ki so bile vključene $\mathrm{v} z$ delom povezano neformalno izobraževanje, večji (glej Sliko 5). 
Slika 5: Struktura vklijučenih v neformalno izobraževanje po namenu vkliučitve, EU-27, 2007, v \%

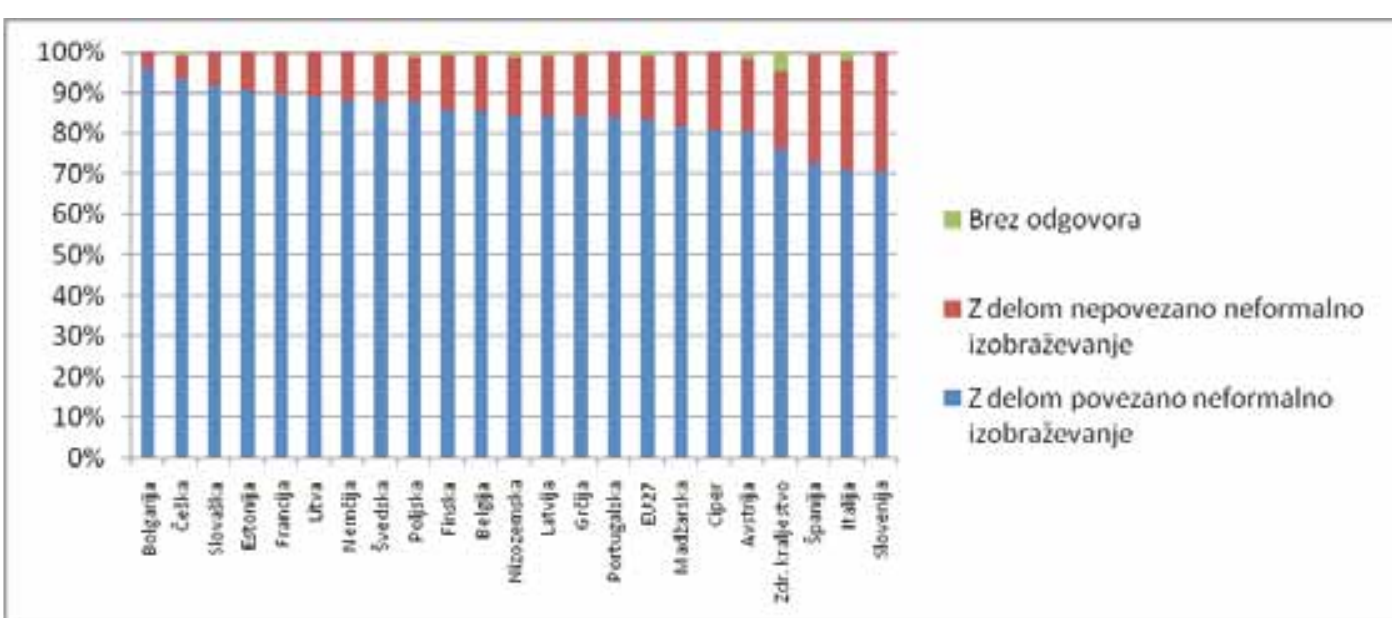

Vir: Eurostat, Anketa o izobraževanju odraslih.

Delež moških, ki so vključeni $\mathrm{v}$ z delom povezano izobraževanje, je podoben kot v povprečju EU-27 in kot v večini drugih držav EU-27 večji od deleža žensk. Glede na starost je podobno kot na ravni povprečja EU-27 ta delež največji v starostni skupini 35-54 let. Pri tej starostni skupini je motiv za izobraževanje, povezan s kariro, najpo

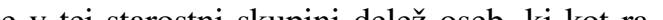
zlog za izobražn zlog za izobraževanje navajajo boljše opravljanje dela in izboljšanje kariernih možnosti, med vsemi starostnimi skupinami največji. Slovenija

po deležu oseb, vključenih $\mathrm{v}$ z delom povezano neformalno izobraževanje, zaostaja za povprečjem EU-27 pri vseh starostnih skupinah. Najmanjši zaostanek je v starostni skupini 35-54 let, največji v starostni skupini 54-64 let, kjer je stopnja delovne aktivnosti precej nižja od povprečja EU-27. Delež oseb, vključ Urecja Eu-27. Dežz oseb, vključenih $\mathrm{v} z$ delom povezano izobraževanje, se z višanjem dosežene izobrazbe povečuje. Slovenija za povprečjem EU-27 najbolj zaostaja pri osebah s srednješolsko izobrazbo, medtem ko je pri osebah z nizko izobrazbo ta delež precej manjši.

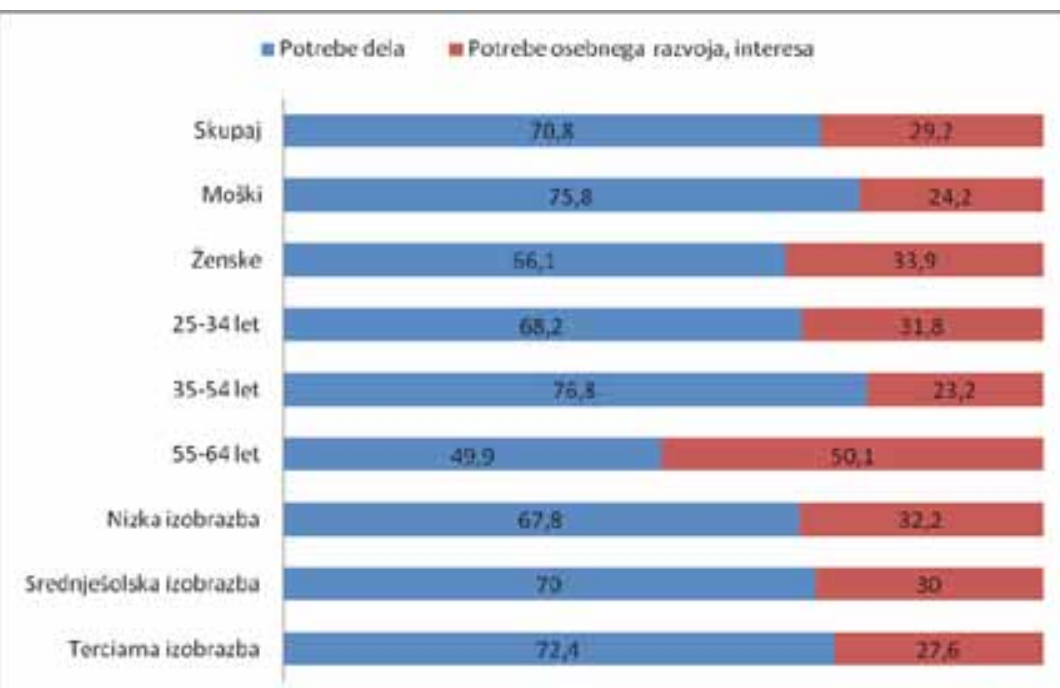

Slika 6: Struktura vkliučenih v neformalno
izobraževanj izobraževanie po skupaj in po spolu, starosti ter izobrazbi,

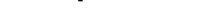

RAZLOGI ZA NEFORMALNO

\section{IZOBRAŽEVANIE}

Razlogi za izobraževanje so lahko povezani s posameznikovim osebnostnim razvojem, zamenjavo službe, napredovanjem na delovnem mestu, družabnimi stiki ipd.

V Sloveniji je najpogostejši razlog za neformalno izobraževanje razvoj kariere ali (in) boljše opravljanje dela, ta motiv je navedlo 54,4 odstotka oseb. Drugi razlogi za nefor-

alno izobraževanje so veliko anj pomembni. Slovenija po deležu oseb, ki navajajo razlog bolje opravljati delo ali (in) izboljšati karierne možnosti, precej presega povprečje EU27 , medtem ko po vseh drugih razlogih za neformalno izobraževanje za evropskim povprečjem zaostaja, najbolj pri razlogu izboljšati znanje o določeni stvari.
$V$ Sloveniji se posamezniki najpogosteje vkljucujejo $\checkmark$ neformalno izobrazevanje zaradi razvoja kariere.

Slika 7: Razlogi za neformalno izobraževanje, Slovenija in povprečie EU-27, 2007, v \%

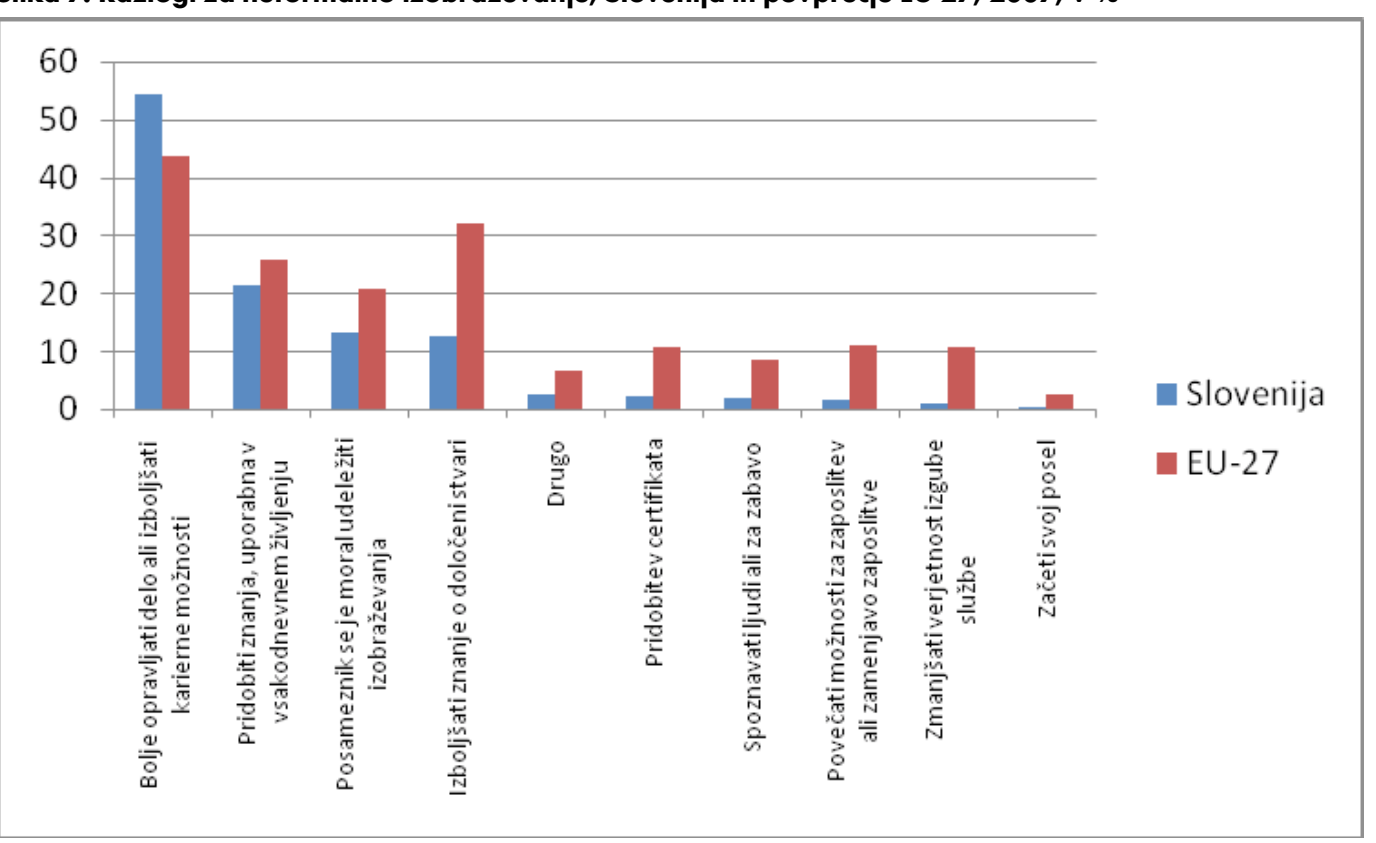

Vir: Eurostat, Anketa o izobraževanju odrasih.

V Anketi o izobraževanju odraslih so razlogi razvrščeni v osem skupin: (i) zmanjšati verjetnost izgube službe, (ii) izobraževanje je bilo obvezno, (iii) povečati možnosti za pridobitev zaposlitve ali zamenjavo obstoječe zaposlitve, (iv) začeti lasten posel, (v) pridobiti v vsakdanjem življenju uporabna znanja in veščine, (vi) izboljšati znanja in veččine o neki stvari, (vi) spoznati nove ljudi ali za zabavo, (vii) pridobiti certifikat, (viii) izboljšati kakovost dela ali karierni razvoj. 
PODROČJA IZOBRAŽEVANIA

Področja izobraževanja odraslih so lahko povezana $\mathrm{z}$ razvojem strokovnega znanja, ki ga zaposleni potrebuje pri delu, ali $\mathrm{z}$ drugimi potrebami. Struktura udeležencev po področjih izobraževanja pokaže, da se jih je podobno kot $\mathrm{v}$ večini drugih držav EU-27 v letu 2007 največji delež udeležil izobraževanj na področju družbenih ved, poslovnih ved in prava. Ta delež je znašal 21,6 odstotka in je bil manjši od povprečja EU-27. Slovenija od

povprečja EU-27 najbolj odstopa po večjem eležu udeležencev izobraževanj za pridobivaje znanja tujih jezikov. Ta delež je tudi med največjimi med državami EU-27, kar glede na majhnost Slovenije ni presenetljivo. Večji od povprečja EU-27 je tudi delež udeležencev izobraževanj s področja humanistike in umetnosti ter v programih uporabe računalnik Slove.ija njolj zaostaja za povprecjem EU ja najbolj zaostaja za povpecjen EU-27 po deležu udeležencev izobraževanj na področju zdravstva in sociale.

\section{Slika 8: Struktura vkliučenih
povpreçie EU-27, 2007, v \%}

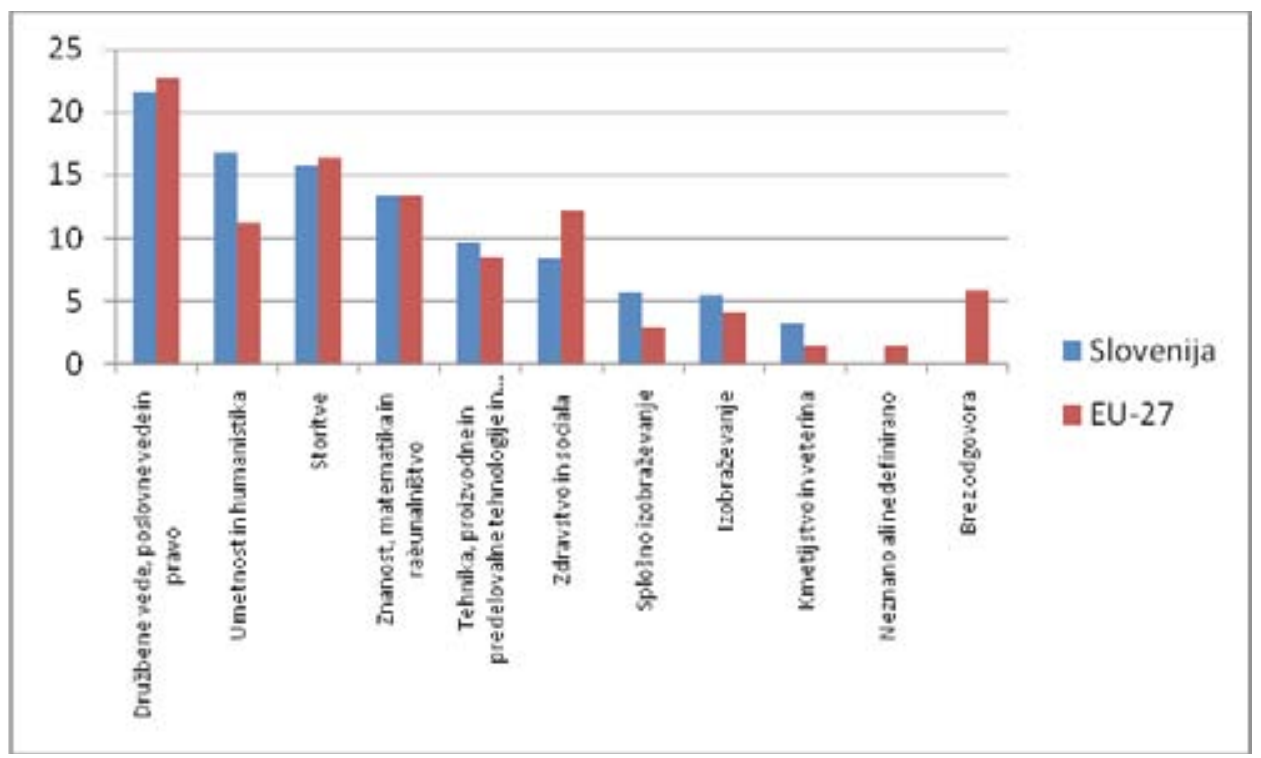

Vir: Eurostat, Anketa o izobraževanju odraslih.

\section{IZVAJALCI NEFORMALNEGA}

\section{ZOBRAŽEVAN|A ODRASLIH}

Neformalno izobraževanje odraslih lahko izvajajo izobraževalne ustanove (za formalno ali neformalno izobraževanje) ali druge organizacije, ki so lahko po svoji osnovni dejavnosti in namenu zelo različne. Te ustanove so lahko podjetje, ki izobraževanje razvija kot dodatno dejavnost, nepridobitne ustano- ve, razna združenja in zbornice, sindikati ipd. Struktura udeležencev neformalnega izobraževanja po izvajalcih pokaže, da so $\mathrm{v}$ letu 2007 največji delež neformalnega izobraževaja izvajule ustanove za neformalo izobraževanje 7 (44,6 odstotka) (glej Sliko 9). S tem Slovenija močno odstopa od povprečja EU-27, kjer je ta delež precej manjši (16,4 odstotka), in se uvršča med države EU-
27 z največjim deležem teh ustanov. $V$ večini drugih držav EU-27 največji delež neformalnega izobraževanja izvaja delodajalec. Na ravni povprečja EU-27 je ta delež znašal

38,4 odstotka. Pri nas je delež delodajalcev, ki so izvajali neformalno izobraževanje, precej manjši, večji pa je delež delodajalski organizacij in trgovinskih zbornic.

Slika 9: Struktura neformalnega izobraževanja po vrstah ustanov, ki so izvajale izobraževanje, Slovenija, $2007, v \%$

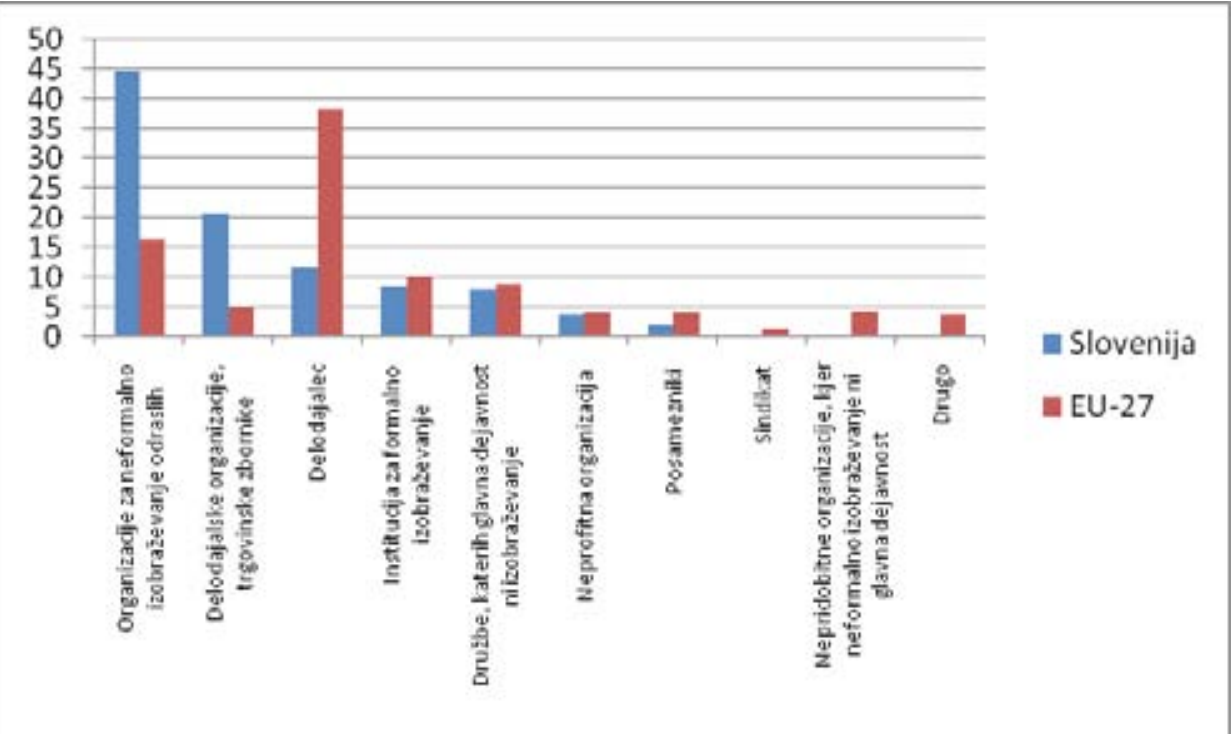

Vir: Eurostat, Anketa o izobraževaniu odraslih.

Ěevanie odraslih so zasebni izvajalci, liudske univerze, izobraževalni centri, iezikonne

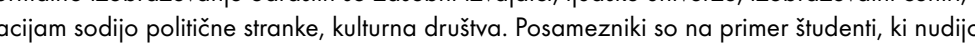

inšrtrukciie.

\section{SKLEP}

Čeprav je mednarodni položaj Slovenije po vključenosti odraslih v neformalno izobraževanje razmeroma ugoden, pa lahko na tem področju opazimo nekatere probleme oziroma izzive.

Pomemben izziv je povečanje vključenost odraslih, predvsem starejših, nizko izobraženih, brezposelnih, posameznikov, ki opravliajo intelektuho panj zahteve poklice, vljajo intelek ino naž $\checkmark$ neformalno izobraževanje. Pri teh osebah je navadno pomembna ovira predrago izobraževanje, ki si ga posameznik ni moge privoščiti. Države poskušajo z raznimi fi- nančnimi in drugimi ukrepi (vavčerji za rač čcki za izobraževaje, oprostite stroškov izobraževanja, davčne olajšave ipd.) povečati vključenost navedenih skupin odraslih v izobraževanje. V Sloveniji so dokumentu Ukrepi države za zaposlovanje ter transferji in subvencije posameznikom in družinam (2009) med kratkoročnimi ukrepi na trgu dela, vseživljenjskega učenja in socialne varnosti predvideni vavčerji izobraževanje zaposlenih. $\mathrm{V}$ prihodnje veljalo okrepiti spodbude za izobraževanj posameznikov, ki si izobraževanja ne morejo 
privoščiti. Obenem bi bilo treba spremljat çinkovitost porabe finančnih sredstev.

Naslednji izziv je izboljšanje krajevne dostopnosti neformalnega izobraževanja. Pomemben dejavnik vključenosti odraslih $\mathrm{v}$ izobraževanje je krajevna dostopnost izobraževanja. Možnost izobraževanja v bližini kraja bivanja oziroma kraja zaposlitve povečuje možnosti prebivalstva za izobraževanje. V Sloveniji je v letu 2007 delež oseb, ki so se želele izobraževati, pa se niso in so kot oviro navedle, da v njihovem okolju izobraževanje ni bilo na voljo, znašal 30,2 odstot$\mathrm{ka}$ in je precej presegal povprečje EU-27. V Sloveniji je mreža ustanov, ki izvajajo neformalno izobraževanje odraslih, razporejena zelo neenakomerno. Število prebivalcev v starosti 15 let ali več na izvajalca neformalnega izobraževanja je bilo v letu 2007/2008 najmanjše $\mathrm{v}$ osrednjeslovenski in gorenjski regiji ter jugovzhodni Sloveniji in največje v zasavski, spodnjeposavski in pomurski regiji. To število je v osrednjeslovenski regiji veliko manjše kot v drugih regijah. Velja bi spodbujati enakomernejšo razporeditev organizacij za izobraževanje odraslih in tako povečevati krajevno dostopnost izobraževanja.

Izziv je tudi izboljšanje informiranosti o možnostih izobraževanja, predvsem pri osebah, ki se redkeje vključujejo v izobraževanje. $\mathrm{K}$ vključitvi posameznika $\mathrm{v}$ izobraževanje lahko pripomorejo tudi dostopne in kakovolahko pripomorejo tudi dostopne in kakovo-
stne informacije o ponudbi izobraževanja stne informacije o ponudbi izobraževanja.
Če ima posameznik na voljo kakovostne inČe ima posameznik na voljo kakovostne informacije o programih in vsebinah, poteku, tnost, da se bo izobraževanja udeležil. Viri informacij o izobraževar posamezniko pok ja okolja in prijatelji, pisni vin in internet ter razne ustanove. Po podatkih Ankete o izobraževanju odraslih je največji delež oseb informacije o možnostih za učenje dobil na internetu.
Toda nizko izobraženi in starejši, ki se redkeje vključujejo v izobraževanje, tudi redkeje uporabljajo internet. Izziv je torej tudi večja uporaba interneta pri teh osebah.

\section{Unesco, OECD, Eurostat.}

Neformalno izobraževanje so namenske in organizirare učne aktivnosti, ki se odvijajo v institucijah ali zunaj inih. Sem sodijo programi za pridobivanje, obnavlianje, azsirjanje, posodabljanje ali poglabljanje znanja, s kalenthipa mogoce pridobiti javno veljavne izobrazbe. Terciarno izobraževanje obsega višješolsko strokovno izobrazevanje, visokosolski dodiplomski studij in visokošolski podiplomski študij (specialistični, magistrski in doktorski študij)

4 Zakonodajalci, visoki uradniki in menedžerji (SKP 1), strokovnjaki (SKP 2), tehniki in drugi strokouni sodelavci (SKP

Industrijski izdelovalci in sestavljavci (SKP 8) in poklici za preprosta dela (SKP 9 ).

vizobǔconice in pososamezniki, ki so bili vključen niki, ki niso bili vključeni v Zas shi izonjalis

ljudske univerze, izobraževalni centri, jezikoune šole ip

\section{LITERATURA IN VIRI}

Akcijski načrt za izobraževanje odrasihi za učenje je veano pravi cas. (2007). Bruselj: Komisija Evropskih skupnosti.

Adult education survey - AES. (2009). Eurostat Metadata in SDDS format: Base page. Dostopno na: http://epp.eurostat.ec.europa.eu/cache/ITY SDDS/EN/trng_aes_base.htm.

Aktivno prebivalstvo (po Anketi o delovni sili). Metodološka pojasnila. (2009). Ljubljana: Statističn urad RS. Dostopno na: http://www.stat.si/doc/ metod_pojasnila/07-008-MP.htm.

Anketa o izobraževanju odraslih, Slovenija. Metodološka pojasnila. (2009). Ljubljana: Statistični urad RS. Dostopno na: http://www.stat.si/doc/ metod_pojasnila/09-272-MP.htm.

Anketa o življenjskih pogojih, Slovenija. Metodoloska pojasnila. (2009). Ljubljana: Statistični urad RS. Dostopno na: http://www.stat.si/doc/metod pojasnila/08-236-MP.htm.

Anketa o porabi časa, Slovenija. Metodološk pojasnila. (2009). Ljubljana: Statistični urad RS. Dostopno na: http://www_stat_si/doc/metod_pojasnila/08-117_MP.htm.

Continuing education and training for young school leavers and adults. Austria (2006/2007). Eurydice, Eurybase. Dostopno na: http://eacea. e?country=AT\&lang=EN\&fragment=479.

Eurostat - Population and social conditions - Education and training.

Fasih, T. (2008). Linking education policy to labour market outcomes. Washington: The Internation World bank. Dostopno na: http://siteresources. worldbank. org/EDUCATION/Resources/ 278200-1099079877269/547664-1208379365576/ DID_Labor_market_outcomes.pdf.

Hollenbeck, K. (2008). »Is there a role for public support of incumbent worker on-the job training?《 Kalamazoo: Upjohn institute for employment research. Dostopno na: http://www.upjohninstitute. org/publications/wp/08-138.pdf.

»Zzobraževanje odraslih (po Anketi o izobraževanju odraslih) 2007 «. Statistične informacije, (2010), št. 3. Ljubljana: Statistični urad RS.

Levin, B. (2003). Approaches to equity in policy for lifelong learning. Pariz: $O E C D$. Dostopno na: http://wwwoecd.org/dataoecd/50/16/38692676. pdf.

Manninen, J. (2006). »Development of participation models. From single predicting elements to education (11-22). Edited papers from the fifth ERDI expert seminar, Bonn, 21-23. 1.2005, Timisoara: Mirton.

Memorandum o vseživljenjskem učenju. (2000). Bruselj: Komisija Evropske skupnosti.

Nadalinje izobraževanje. Metodološka pojasnila. (2009). Ljubjana. Statistični urad RS. Dostopno na: http://www

Okvir gospodarskih in socialnih reform za povečanje blaginje v Sloveniji. (2005). Ljubljana: Služba ade RS za razvoj.

Operativni program razvoja človeških virov za obdoRS 2007-2013. (2007). Ljubljana: Služba vlade oupravo in regionalno politiko. Pfeiffer, F. (2000). Training and individual perfortric studies. ZEW discussion papers No 00-28. Mannheim: Center for European Economic Research. Dostopno na: http://opus.zbw-kiel.de/ volltexte/2007/5311/pdf/dp0028.pdf.

Podatki o nadalinjem izobraževanju za leto 007/2008. Ljubljana: Statistični urad RS.

SI-STAT podatkovni portal. Demografsko in social področje - Prebivalstvo. Ljubljana: Statistični

Skill needs in Europe. Focus on 2020. (2008). Cedefop Panorama series, 160. Luxembourg: Office for official publications of the European Communities. Dostopno na: http:// www.cedefop.europa.eu/etv/Upload/Information_resources/Bookshop/498/5191_en.pdf.

Sporočilo Komisije Svetu in Evropskemu parlamentu Učinkovitost in pravičnost v evropskih sistemih izobraževanja in usposabljanja. (2006). Bruselj, Uradni list Evropske unije 8. 9. 2006.

Sporočilo Komisije Izobraževanje odraslih: Za učenje ni nikoli prepozno. (2006). Bruselj: komisija

Strategija vseživljenjskosti učenja. (2007). (Jelenc, Z., ur.). Ljubljana: Ministrstvo za šolstvo in šport, Pedagoški inštitu

Strategija razvoja Slovenije. (2005). Ljubljana: Urad RS za makroekonomske analize in razvoj.

Ukrepi države za zaposlovanje ter transferji in subvencije posameznikom in družinam. (2009). Ljubljana: Ministrstrtvo za delo, družino in socialne fileadmin/mddsz.gov.si/pageuploads/dokume ti_pdf/ukrepi_zaposl_transferji_200309.pdf. "Vseživljenjsko učenje 2002-2003«. Statistične infor macije, 2004, št. 118. Ljubljana: SURS. 